\title{
Determinants of obesity in population of PURE study from Lower Silesia
}

\author{
Czynniki wpływające na występowanie otyłości w populacji badania PURE \\ z rejonu Dolnego Śląska
}

\author{
Aleksandra Zdrojowy-Wełna ${ }^{1}$, Katarzyna Zatońska ${ }^{2}$, Grażyna Bednarek-Tupikowska' ${ }^{1}$, \\ Alicja Jokiel-Rokita ${ }^{3}$, Katarzyna Kolačkov ${ }^{1}$, Andrzej Szuba ${ }^{4}$, Marek Bolanowski' \\ ${ }^{1}$ Department of Endocrinology, Diabetes and Isotope Therapy, Wroclaw Medical University, Wroclaw, Poland \\ ${ }^{2}$ Department of Social Medicine, Wroclaw Medical University, Wroclaw, Poland \\ ${ }^{3}$ Faculty of Pure and Applied Mathematics, Wroclaw University of Science and Technology, Wroclaw, Poland \\ ${ }^{4}$ Faculty of Health Science, Wroclaw Medical University, Wroclaw, Poland
}

\begin{abstract}
Introduction: The knowledge about obesity pathogenesis is insufficient. The aim of our study was to investigate environmental and individual determinants of obesity in population of PURE study from Lower Silesia.

Material and methods: This was a cross sectional observation of 1064 inhabitants of Wroclaw and neighbouring rural area (671 women, 393 men), who took part in PURE study in years 2007-2010. Each participant answered PURE questionnaire and International Physical Activity Questionnaire providing information about obesity risk factors. Anthropometric measurements were collected, blood samples were taken for assessment of FTO gene polymorphism. A stepwise logistic regression analysis was performed to identify the most significant predictors of obesity.

Results: $31 \%$ of the study group had obesity (BMI over $30 \mathrm{~kg} / \mathrm{m}^{2}$, no difference between men and women), overweight (BMI $25-29.9 \mathrm{~kg} / \mathrm{m}^{2}$ ) affected $48.1 \%$ of men and $36.7 \%$ of women. Determinants of obesity in female group were: rural inhabitancy, chronic medication, unemployment, age, sedentary leisure time activity, non-smoking, hypertension in family, family related stress $(\mathrm{p}=0.66$ in the Hosmer-Lemeshow test). Determinants of obesity in male group were rural inhabitancy, chronic medication, family related stress, diabetes in family ( $p=0.27$ in the Hosmer-Lemeshow test). Risk factors for central obesity were similar, however in women oral contraception and physical activity were associated with lower obesity risk.

Conclusions: Environmental factors, especially rural inhabitancy and family related stress were associated with higher obesity risk in our study. Employment, smoking, physical activity and use of oral contraception seemed to have protective role in women. (Endokrynol Pol 2018; 69 (6): 644-652)
\end{abstract}

Key words: obesity; risk factors; rural; urban; environmental

\section{Streszczenie}

Wstęp: Wiedza na temat patogenezy otyłości jest niewystarczająca. Celem badania była ocena środowiskowych oraz indywidualnych czynników ryzyka otyłości w populacji badania PURE z rejonu Dolnego Śląska.

Materiał i metody: W obserwacyjnym, przekrojowym badaniu oceniono 1064 mieszkańców Wrocławia i okolic wiejskich (671 kobiet, 393 mężczyzn), uczestniczących w projekcie PURE w latach 2007-2010. Badani odpowiedzieli na pytania z kwestionariusza PURE oraz Międzynarodowego Kwestionariusza Aktywności Fizycznej (IPAQ), co dostarczyło informacji na temat czynników ryzyka otyłości. U uczestników wykonano pomiary antropometryczne oraz pobrano krew na badanie polimorfizmu genu FTO. W modelu regresji logistycznej, korzystając z metody krokowej wstecznej, oceniono, które czynniki mają istotny związek z występowaniem otyłości.

Wyniki: Otyłość (BMI > $30 \mathrm{~kg} / \mathrm{m}^{2}$ ) stwierdzono u 31\% badanych niezależnie od płci, nadwaga (BMI 25-29,9 kg/m²) dotyczyła 48,1\% mężczyzn oraz 36,7\% kobiet. Czynnikami związanymi z występowaniem otyłości w grupie kobiet były: zamieszkanie na wsi, przewlekłe stosowanie leków, brak zatrudnienia, wiek, siedzący tryb spędzania czasu wolnego, niepalenie papierosów, nadciśnienie tętnicze w wywiadzie rodzinnym, stres związany z rodziną ( $\mathrm{p}=0,66 \mathrm{w}$ teście Hosmera-Lemeshowa). W grupie mężczyzn były to: zamieszkanie na wsi, przewlekłe stosowanie leków, stres związany z rodziną, cukrzyca w wywiadzie rodzinnym ( $\mathrm{p}=0,27 \mathrm{w}$ teście Hosmera-Lemeshowa). Podobne czynniki sprzyjały występowaniu otyłości centralnej. Wśród kobiet stosowanie tabletek antykoncepcyjnych oraz aktywność fizyczna wiązały się z mniejszym ryzykiem otyłości.

Wnioski: Czynniki środowiskowe, szczególnie zamieszkanie na wsi i stres, były związane z większym ryzykiem występowania otyłości wśród badanych. Zatrudnienie, palenie papierosów, aktywność fizyczna oraz stosowanie tabletek antykoncepcyjnych wiązały się z rzadszym występowaniem otyłości u kobiet. (Endokrynol Pol 2018; 69 (6): 644-652)

Słowa kluczowe: otyłość; czynniki ryzyka; wiejskie; miejskie; środowiskowe 


\section{Introduction}

Obesity is a major problem of public health globally. Although many preventive actions have been undertaken, no country in the world has managed to reverse obesity epidemic once it has begun [1].

Apart from the fundamental cause of adiposity - positive energy balance between calorie intake and output, there are more predisposing factors. The upstream determinants of obesity are defined as factors beyond the control of individual. We can divide them into physical (e.g. architecture), socio-cultural (attitudes and beliefs), economic and political [2]. They play a great role in population's health, for example social deprivation has been associated with excessive weight [3]. However, the upstream determinants of obesity are very problematic to examine and data on environmental adiposity risk factors are lacking. Knowledge about obesity pathogenesis is crucial to design preventive actions. Recently, the need to implement community-based strategies has been underlined [4].

The aim of our study was to investigate factors that influence obesity in population of Lower Silesia, a region with high prevalence of obesity [5]. We examined a wide range of obesity determinants, both individual and environmental.

\section{Material and Methods}

\section{Study population}

The study group consisted of 1064 inhabitants of Wroclaw and neighbouring rural area (671 women, 393 men aged $30-80$ years), who took part in the Prospective Urban Rural Epidemiology Study (PURE Study) in years 2007-2010. Each participant has given oral and written consent. The study has been approved by Wroclaw Medical University Ethical Committee (KB 443/2006). The aims and design of PURE Study have been published elsewhere [6].

\section{Study protocol}

Each participant answered PURE Questionnaire and International Physical Activity Questionnaire (IPAQ) collected by a trained person. It provided information about possible individual and environmental obesity risk factors (listed in Table I). Participants were categorized to low, moderate or high level of activity according to Guidelines for the data processing and analysis of IPAQ [www.ipaq.ki.se].

From each participant a blood sample was taken for the genetic examination (presence of the allele A or $\mathrm{T}$ of the FTO — fat mass and obesity-associated gene polymorphism rs9939609).
Table I. Potential variables related to obesity considered in our analysis

Tabela I. Zmienne potencjalnie zwiq̨zane $z$ występowaniem otyłości rozważane w trakcie analizy

\begin{tabular}{|c|c|}
\hline Variable & Categories \\
\hline Age & Years (numerical value) \\
\hline Inhabitancy & Urban, rural \\
\hline Education & $\begin{array}{l}\text { No/ground school, } \\
\text { occupational school, college, } \\
\text { university }\end{array}$ \\
\hline Marital status & $\begin{array}{l}\text { Divorced, currently married, } \\
\text { never married, widowed }\end{array}$ \\
\hline Employment & No, yes \\
\hline Chronic use of medications & No, yes \\
\hline Personal and family health history & $\begin{array}{l}\text { Diabetes, coronary heart } \\
\text { disease, hypertension, stroke }\end{array}$ \\
\hline Oral contraception (in women) & No, yes \\
\hline $\begin{array}{l}\text { Injury in the previous year causing } \\
\text { disability }\end{array}$ & No, yes \\
\hline Average sleep duration & $\begin{array}{l}\text { Under } 6 h \text {, from } 6 h \text { to } 8 h \text {, } \\
\text { from } 8 \mathrm{~h} \text { to } 10 \mathrm{~h} \text { and above } 10 \mathrm{~h}\end{array}$ \\
\hline Smoking status & Never, current, former \\
\hline Regular alcohol use & Never, current, former \\
\hline $\begin{array}{l}\text { Symptoms of depression (according } \\
\text { to DSM-IV) }\end{array}$ & No, yes \\
\hline $\begin{array}{l}\text { Work related stress: loss of job, } \\
\text { retirement, loss of harvest, new job }\end{array}$ & Yes, no (in the previous year) \\
\hline $\begin{array}{l}\text { Family related stress: divorce, } \\
\text { death of a spouse, death of other } \\
\text { family member, birth, wedding, long } \\
\text { separation from family }\end{array}$ & Yes, no (in the previous year) \\
\hline $\begin{array}{l}\text { Other stress: injury, conflict, robbery, } \\
\text { violence, other }\end{array}$ & Yes, no (in the previous year) \\
\hline $\begin{array}{l}\text { How advertisement influence } \\
\text { person's food choices }\end{array}$ & Not at all, partly, significantly \\
\hline Spending leisure time & Sedentary, non-sedentary \\
\hline Average walking time per day & Minutes (numerical value) \\
\hline $\begin{array}{l}\text { Average physical inactivity (sitting } \\
\text { time) per day }\end{array}$ & Minutes (numerical value) \\
\hline $\begin{array}{l}\text { Physical activity: evaluated on the } \\
\text { basis of IPAO }\end{array}$ & Low, moderate, high \\
\hline $\begin{array}{l}\text { Presence of the rs9939609 FTO } \\
\text { gene risk allele }-\mathrm{A}\end{array}$ & Yes, no \\
\hline
\end{tabular}

DSM-IV — Diagnostic and Statistical Manual of Mental Disorders; IPAO — International Physical Activity Questionnaire

The physical examination included measurement of height in cm (in Frankfurt plane, accuracy of 0.5 $\mathrm{cm}$ ), weight in $\mathrm{kg}$ (calibrated Tanita scales, accuracy of $0.1 \mathrm{~kg}$ ). The body mass index (BMI) was calculated: $\mathrm{BMI}=$ weight $[\mathrm{kg}] /$ height $[\mathrm{m}]^{2}$. The waist circumference was measured with tape, in $\mathrm{cm}$, halfway between the lowest rib and the top of the hipbone. The hip circum- 
ference was measured with tape, in $\mathrm{cm}$, at the widest part of the buttocks. The waist-to-hip ratio (WHR) was calculated: WHR $=$ waist circumference $[\mathrm{cm}] /$ hip circumference [cm].

Obesity was defined on the basis of three criteria:

- BMI > $30 \mathrm{~kg} / \mathrm{m}^{2}$ (BMI-obesity);

- waist circumference in women $>88 \mathrm{~cm}$ and in men > $102 \mathrm{~cm}$ (waist-obesity);

- WHR in women $>0.85$ and in men $>0.9$ (WHR-obesity).

\section{Genotyping}

Methods are described in the Supplementary Material.

\section{Statistical analysis}

Statistical analysis were performed via STATISTICA (version 13.1) for Windows.

We described variables using elements of descriptive statistics that included: minimum and maximum value, mean and standard deviation. For qualitative data contingency tables were created. We used $\chi^{2}$ test to verify hypothesis of independence between qualitative data. Subjects were divided into two groups, no obese or obese, according to the three obesity criteria presented in the Study protocol. We performed a stepwise logistic regression analysis with score Rao test and Wald test to identify the most significant predictors of obesity (on the 0.1 significance level) from the potential variables listed in Table I. A significance of association of chosen predictors with the probability of the obesity was tested by the likelihood ratio test. We used Hosmer-Lemeshow test to examine goodness-of-fit of the selected models. Frequencies of the observed FTO gene alleles were tested against the Hardy-Weinberg equilibrium. We performed the analysis separately in women and men.

\section{Results}

\section{General characteristic of the study group}

We enrolled 1064 people, 671 women and 393 men, with mean age $54.2 \pm 9.2$ years (min. 30, max. 83). Women were older than men $(54.3 \pm 8.9$ vs. $53.9 \pm 9.8$ years $)$ ( $p<0.05$ ). $36 \%$ of the group lived in the rural area, $64 \%$ in Wroclaw (no differences between men and women, $\mathrm{p}=0.21$ ). Significantly more men than women were currently employed $(67.4 \%$ vs. $54.3 \%$, p < 0.0001). $19.7 \%$ of women and $22.9 \%$ of men were currently smoking. $65.1 \%$ of women and $78.6 \%$ of men currently used alcohol products ( $\mathrm{p}<0.0001$ ). About $70 \%$ of the participants were qualified to the category of high level of physical activity based on the IPAQ results (no difference between men and women, $\mathrm{p}=0.12$ ). Average physical inactivity (sitting) time per day was similar in men and women (171.7 \pm 83.7 minutes per day). The frequency of FTO rs 9939609 risk allele (A) was 0.44 .

\section{Obesity measurements in the study group}

Prevalence of obesity $\left(\mathrm{BMI}>30 \mathrm{~kg} / \mathrm{m}^{2}\right)$ was similar in both sex groups - about $31 \%$. Overweight (BMI between 25 and $29.9 \mathrm{~kg} / \mathrm{m}^{2}$ ) affected $48.1 \%$ of men and $36.7 \%$ of women ( $<<0.0001)$. Mean BMI in the study group was $28.2 \pm 5.1 \mathrm{~kg} / \mathrm{m}^{2}$ and was significantly higher in men $\left(28.5 \pm 4.4 \mathrm{~kg} / \mathrm{m}^{2}\right)$ than in women $\left(28 \pm 5.5 \mathrm{~kg} / \mathrm{m}^{2}\right)(\mathrm{p}<0.01)$.

Men had higher mean waist circumference than women $(98.9 \pm 11.9 \mathrm{~cm}$ vs. $88.1 \pm 13.4 \mathrm{~cm})$. On the basis of the waist circumference obesity criterion more women were obese than men ( $45.9 \%$ vs. $33.8 \%, \mathrm{p}=0.0001)$.

Mean WHR in female group was $0.84 \pm 0.07$ and in male group $-0.96 \pm 0.07 .39 .3 \%$ of women and $82.4 \%$ of men had WHR indicating central obesity ( $p<0.0001)$.

\section{Obesity determinants in the group of women}

Determinants of obesity in female group were:

- for the BMI-obesity: chronic medication, unemployment, rural inhabitancy, older age, sedentary leisure time activity, non-smoking, hypertension in family, family related stress $(p=0.66$ in the Hosmer-Lemeshow test). Genetic variable was insignificant in the first step of the logistic regression analysis and was not considered in the further model (AA vs. TT: $\mathrm{p}=0.87, \mathrm{AA}+$ AT vs. TT: $\mathrm{p}=0.69$ in Wald test);

- for the waist-obesity: unemployment, rural inhabitancy, chronic medication, family related stress, other stress, hypertension in family, no oral contraception, non-smoking, sedentary leisure time activity, injury causing disability $(\mathrm{p}=0.28$ in the Hosmer-Lemeshow test). Genetic variable was insignificant in the first (AA + AT vs. TT) and third (AA vs. TT) step of the logistic regression analysis and was not considered in the further model (AA vs. TT: $\mathrm{p}=0.15, \mathrm{AA}+\mathrm{AT}$ vs. TT: $\mathrm{p}=0.68$ in Wald test);

- for the WHR-obesity: unemployment, rural inhabitancy, chronic medication, family related stress, other stress, hypertension in family, low physical activity ( $p=0.55$ in the Hosmer-Lemeshow test). Genetic variable was insignificant in the first step of the logistic regression analysis and was not considered further in the model (AA vs. TT: $p=0.89$, $\mathrm{AA}+\mathrm{AT}$ vs. TT: $\mathrm{p}=0.3$ in Wald test).

Table II contains the estimates of the logistic regression coefficients with the BMI-obesity as the dependent variable and the chosen independent variables. Analogous results are presented in Tables III with the waist-obesity and Table IV with WHR-obesity. 
Table II. Significant variables associated with BMI-obesity in the group of women

Tabela II. Zmienne istotnie związane z występowaniem otyłości (wg BMI) w badanej grupie kobiet

\begin{tabular}{|c|c|c|c|c|c|}
\hline Factor & $\begin{array}{c}\text { Estimate of the } \\
\text { coeff. }\end{array}$ & $\begin{array}{c}\text { Frequency (\%) } \\
\text { No obese / Obese }\end{array}$ & p value* & Odds Ratio & $95 \% \mathrm{Cl}$ \\
\hline Employment & & & 0.06 & & \\
\hline Yes & -0.21 & 78.2 / 21.8 & & & \\
\hline No & 0.21 & $58.8 / 41.2$ & & 1.52 & $0.98-2.36$ \\
\hline Inhabitancy & & & 0.001 & & \\
\hline Urban & -0.31 & $74 / 26$ & & & \\
\hline Rural & 0.31 & $60.2 / 39.8$ & & 1.86 & $1.28-2.7$ \\
\hline Chronic medication & & & 0.002 & & \\
\hline Yes & 0.33 & $62 / 38$ & & & \\
\hline No & -0.33 & $80.5 / 19.5$ & & 0.52 & $0.34-0.8$ \\
\hline Family related stress & & & 0.07 & & \\
\hline Yes & 0.17 & $64.6 / 35.4$ & & & \\
\hline No & -0.17 & $71.9 / 28.1$ & & 0.72 & $0.5-1.02$ \\
\hline Hypertension in family & & & 0.03 & & \\
\hline Yes & 0.21 & $66.7 / 33.3$ & & & \\
\hline No & -0.21 & $72.8 / 27.2$ & & 0.66 & $0.45-0.97$ \\
\hline Smoking & & & 0.03 & & \\
\hline Never & 0.15 & $66.2 / 33.8$ & & 0.86 & $0.57-1.3$ \\
\hline Formerly & 0.3 & $65.6 / 34.4$ & & & \\
\hline Currently & -0.45 & $80.3 / 19.7$ & & 0.47 & $0.27-0.84$ \\
\hline Leisure time activity & & & 0.01 & & \\
\hline Sedentary & 0.25 & $65.7 / 34.3$ & & 1.64 & $1.11-2.42$ \\
\hline \multirow[t]{2}{*}{ Nonsedentary } & -0.25 & $75 / 25$ & & & \\
\hline & 0.03 & & 0.02 & 1.03 & $1-1.06$ \\
\hline
\end{tabular}

${ }^{*} p$ value in the likelihood ratio test with remaining variables in the model; $\mathrm{Cl}$ — confidence interval

\section{Obesity determinants in the group of men}

Determinants of obesity in male group were:

- for the BMI-obesity: chronic medication, rural inhabitancy, family related stress, diabetes in family ( $p=0.27$ in the Hosmer-Lemeshow test). Genetic variable was on the border of statistical significance (AA vs. TT and AA + AT vs. TT: $\mathrm{p}=0.06$ in Wald test);

- for the waist-obesity: rural inhabitancy, physical inactivity time, chronic medication, diabetes in family ( $p=0.63$ in the Hosmer-Lemeshow test). Genetic variable was insignificant in the second step of the logistic regression analysis and was not considered further in the model (AA vs. TT: $p=0.23, A A+A T$ vs. TT: $p=0.11$ in Wald test);

- for the WHR-obesity: older age, chronic medication, rural inhabitancy, diabetes in family ( $p=0.64$ in the Hosmer-Lemeshow test). Genetic variable was insignificant in the third step of the logistic regression analysis and was not considered further in the model (AA vs. TT: $\mathrm{p}=0.1, \mathrm{AA}+$ AT vs. TT: $\mathrm{p}=0.09$ in Wald test).

Table $\mathrm{V}$ contains the estimates of the logistic regression coefficients with the BMI-obesity as the dependent variable and the chosen independent variables. Analogous results are presented in Tables VI with the waist-obesity and Table VII with the WHR-obesity.

\section{Discussion}

In our analysis of 1064 inhabitants of Lower Silesia, many factors were significantly associated with the occurrence of obesity. The first group of determinants referred to the environmental background (rural inhabitancy, unemployment, stress), another to the individual biologic predisposition (age, chronic medication, family predisposition to diseases) and third to lifestyle factors (non-smoking status, sedentary leisure time, physical inactivity time). 
Table III. Significant variables associated with the waist-obesity in the group of women

Tabela III. Zmienne istotnie związane z występowaniem otyłości (wg obwodu talii) w badanej grupie kobiet

\begin{tabular}{|c|c|c|c|c|c|}
\hline Factor & $\begin{array}{c}\text { Estimate of the } \\
\text { coeff. }\end{array}$ & $\begin{array}{c}\text { Frequency (\%) } \\
\text { No obese / Obese }\end{array}$ & p value ${ }^{*}$ & Odds Ratio & $95 \% \mathrm{Cl}$ \\
\hline Employment & & & $<0.0001$ & & \\
\hline Yes & -0.48 & $67.5 / 32.5$ & & & \\
\hline No & 0.48 & $38.2 / 61.8$ & & 2.62 & $1.81-3.79$ \\
\hline Inhabitancy & & & 0.0001 & & \\
\hline Urban & -0.38 & $63.1 / 36.9$ & & & \\
\hline Rural & 0.38 & 39 / 61 & & 2.14 & $1.45-3.18$ \\
\hline Chronic medication & & & $<0.0001$ & & \\
\hline Yes & 0.42 & $45.8 / 54.2$ & & & \\
\hline No & -0.42 & $68.3 / 31.7$ & & 0.43 & $0.29-0.64$ \\
\hline Family related stress & & & 0.001 & & \\
\hline Yes & 0.28 & 47.4 / 52.6 & & & \\
\hline No & -0.28 & $59.1 / 40.9$ & & 0.56 & $0.39-0.8$ \\
\hline Other stress & & & 0.005 & & \\
\hline Yes & -0.27 & $61.7 / 38.3$ & & & \\
\hline No & 0.27 & $48.1 / 51.9$ & & 1.73 & $1.17-2.55$ \\
\hline Hypertension in family & & & 0.005 & & \\
\hline Yes & 0.27 & $51.2 / 48.8$ & & & \\
\hline No & -0.27 & $59.3 / 40.7$ & & 0.58 & $0.4-0.85$ \\
\hline Oral contraception & & & 0.03 & & \\
\hline Yes & -0.25 & $71.8 / 28.2$ & & & \\
\hline No & 0.25 & $48.6 / 51.4$ & & 1.66 & 1.052 .63 \\
\hline Smoking & & & 0.02 & & \\
\hline Never & 0.12 & $51.4 / 48.6$ & & 0.82 & $0.54-1.24$ \\
\hline Formerly & 0.32 & $51.1 / 48.9$ & & & \\
\hline Currently & -0.44 & 65.2 / 34.8 & & 0.47 & $0.27-0.81$ \\
\hline Leisure time activity & & & 0.05 & & \\
\hline Sedentary & 0.19 & $50.4 / 49.6$ & & 1.45 & $0.99-2.12$ \\
\hline Nonsedentary & -0.19 & $61.2 / 38.8$ & & & \\
\hline Injury & & & 0.09 & & \\
\hline Yes & 0.32 & $51.2 / 48.8$ & & & \\
\hline No & -0.32 & $54.2 / 45.8$ & & 0.53 & $0.25-1.11$ \\
\hline
\end{tabular}

${ }^{*} p$ value in the likelihood ratio test with remaining variables in the model; $\mathrm{Cl}$ — confidence interval

Our results indicate, that prevalence of obesity in Lower Silesia is high. About $31 \%$ of the study group had BMI over $30 \mathrm{~kg} / \mathrm{m}^{2}$, additionally $48.1 \%$ of men and $36.7 \%$ of women were overweight. Even more participants were diagnosed with central obesity on the basis of waist circumference $(45.9 \%$ of women and $33.8 \%$ of men) or WHR (39.3\% women and $82.4 \%$ of men). This results are worse than data from most studies from Poland. In the biggest Polish epidemiologic multi-centre study - WOBASZ, the prevalence of obesity was $21 \%$ of population and overweight affected $40.2 \%$ of men and $27.7 \%$ of women [7]. Ten years later in WOBASZ II study the prevalence of obesity increased to $24.4 \%$ of men and $25 \%$ of women. However, the frequency of abdominal obesity based on waist circumference in WOBASZ II study was similar to our results $(32.2 \%$ of men and $45.7 \%$ of women) [8]. In another study, NATPOL 2011, the prevalence of obesity was $23.6 \%$ of men and $19.7 \%$ of women [9]. One of the reasons why our findings suggest higher occurrence of obesity than other studies 
Table IV. Significant variables associated with the WHR-obesity in the group of women

Tabela IV. Zmienne istotnie zwiqzane z występowaniem otyłości (wg WHR) w badanej grupie kobiet

\begin{tabular}{|c|c|c|c|c|c|}
\hline Factor & $\begin{array}{c}\text { Estimate of the } \\
\text { coeff. }\end{array}$ & $\begin{array}{c}\text { Frequency (\%) } \\
\text { No obese / Obese }\end{array}$ & p value* & Odds Ratio & $95 \% \mathrm{Cl}$ \\
\hline Employment & & & $<0.0001$ & & \\
\hline Yes & -0.63 & $74.8 / 25.2$ & & & \\
\hline No & 0.63 & 44.2 / 55.8 & & 3.49 & $2.42-5.05$ \\
\hline Inhabitancy & & & 0.0006 & & \\
\hline Urban & -0.33 & $69.8 / 30.2$ & & & \\
\hline Rural & 0.33 & $45.4 / 54.6$ & & 1.95 & $1.33-2.85$ \\
\hline Chronic medication & & & 0.0001 & & \\
\hline Yes & 0.38 & $53.3 / 46.7$ & & & \\
\hline No & -0.38 & $73.2 / 26.8$ & & 0.46 & $0.31-0.69$ \\
\hline Family related stress & & & 0.02 & & \\
\hline Yes & 0.21 & $55.6 / 44.4$ & & & \\
\hline No & -0.21 & $64.1 / 35.9$ & & 0.66 & $0.46-0.94$ \\
\hline Other stress & & & 0.0006 & & \\
\hline Yes & -0.33 & $69.5 / 30.5$ & & & \\
\hline No & 0.33 & $53.7 / 46.3$ & & 1.95 & $1.33-2.87$ \\
\hline Hypertension in family & & & 0.02 & & \\
\hline Yes & 0.22 & $58 / 42$ & & & \\
\hline No & -0.22 & $65.4 / 34.6$ & & 0.65 & $0.44-0.94$ \\
\hline Physical activity (IPAQ) & & & 0.04 & & \\
\hline Low & 0.2 & $55.6 / 44.4$ & & 1.03 & $0.36-2.94$ \\
\hline Moderate & -0.36 & $67.4 / 32.6$ & & 0.59 & $0.39-0.9$ \\
\hline High & 0.16 & $58.5 / 41.5$ & & & \\
\hline
\end{tabular}

${ }^{*} p$ value in the likelihood ratio test with remaining variables in the model; IPAQ — International Physical Activity Questionnaire; WHR — waist-hip ratio

Table V. Significant variables associated with BMI-obesity in the group of men

Tabela V. Zmienne istotnie związane z występowaniem otyłości (wg BMI) w badanej grupie mężczyzn

\begin{tabular}{|c|c|c|c|c|c|}
\hline Factor & $\begin{array}{c}\text { Estimate of the } \\
\text { coeff. }\end{array}$ & $\begin{array}{c}\text { Frequency (\%) } \\
\text { No obese / Obese }\end{array}$ & p value* & Odds Ratio & $95 \% \mathrm{Cl}$ \\
\hline Inhabitancy & & & 0.01 & & \\
\hline Urban & -0.32 & $73.6 / 26.4$ & & & \\
\hline Rural & 0.32 & $59.8 / 40.2$ & & 1.9 & $1.17-3.08$ \\
\hline Chronic medication & & & 0.01 & & \\
\hline Yes & 0.32 & $63.1 / 36.9$ & & & \\
\hline No & -0.32 & $75.3 / 24.7$ & & 0.53 & $0.33-0.84$ \\
\hline Stress (family) & & & 0.03 & & \\
\hline Yes & 0.26 & $63.1 / 36.9$ & & & \\
\hline No & -0.26 & $72.9 / 27.1$ & & 0.6 & $0.37-0.95$ \\
\hline Family health history (diabetes) & & & 0.09 & & \\
\hline Yes & 0.24 & $61.6 / 38.4$ & & & \\
\hline No & -0.24 & $71 / 29$ & & 0.62 & $0.36-1.08$ \\
\hline
\end{tabular}

${ }^{*} p$ value in the likelihood ratio test with remaining variables in the model; $\mathrm{Cl}$ - confidence interval 
Table VI. Significant variables associated with the waist-obesity in the group of men

Tabel VI. Zmienne istotnie związane z występowaniem otyłości (wg obwodu talii) w badanej grupie mężczyzn

\begin{tabular}{|c|c|c|c|c|c|}
\hline Factor & $\begin{array}{c}\text { Estimate of the } \\
\text { coeff. }\end{array}$ & $\begin{array}{c}\text { Frequency (\%) } \\
\text { No obese / Obese }\end{array}$ & p value* & Odds Ratio & $95 \% \mathrm{Cl}$ \\
\hline Inhabitancy & & & 0.000427 & & \\
\hline Urban & -0.43 & $72.8 / 27.2$ & & & \\
\hline Rural & 0.43 & $53 / 47$ & & 2.34 & $1.46-3.76$ \\
\hline Chronic medication & & & 0.021575 & & \\
\hline Yes & 0.27 & $59.6 / 40.4$ & & & \\
\hline No & -0.27 & $73.2 / 26.8$ & & 0.59 & $0.37-0.93$ \\
\hline Family health history (diabetes) & & & 0.085713 & & \\
\hline Yes & 0.24 & $59.3 / 40.7$ & & & \\
\hline No & -0.24 & $68.1 / 31.9$ & & 0.62 & $0.36-1.07$ \\
\hline Average sitting total & 0.003 & & 0.015224 & 1.00 & $1-1.005$ \\
\hline
\end{tabular}

${ }^{*} p$ value in the likelihood ratio test with remaining variables in the model; $\mathrm{Cl}$ - confidence interval

Table VII. Significant variables associated with the WHR-obesity in the group of men

Tabela VII. Zmienne istotnie związane z występowaniem otyłości (wg WHR) w badanej grupie mężczyzn

\begin{tabular}{|c|c|c|c|c|c|}
\hline Factor & $\begin{array}{c}\text { Estimate of the } \\
\text { coeff. }\end{array}$ & $\begin{array}{c}\text { Frequency (\%) } \\
\text { No obese / Obese }\end{array}$ & p value* & Odds Ratio & $95 \% \mathrm{Cl}$ \\
\hline Inhabitancy & & & 0.041614 & & \\
\hline Urban & -0.33 & $20.3 / 79.7$ & & & \\
\hline Rural & 0.33 & $12.1 / 87.9$ & & 1.94 & $1-3.74$ \\
\hline Chronic medication & & & 0.046839 & & \\
\hline Yes & 0.32 & $10.8 / 89.2$ & & & \\
\hline No & -0.32 & $24.7 / 75.3$ & & 0.53 & $0.28-0.99$ \\
\hline Family health history (diabetes) & & & 0.046142 & & \\
\hline Yes & 0.39 & $10.5 / 89.5$ & & & \\
\hline No & -0.39 & $19.5 / 80.5$ & & 0.46 & $0.2-1.04$ \\
\hline Age & 0.054 & & 0.000828 & 1.06 & $1.02-1.09$ \\
\hline
\end{tabular}

${ }^{*} \mathrm{p}$ value in the likelihood ratio test with remaining variables in the model; WHR — waist-hip ratio; Cl — confidence interval

might be older age of our participants. Excessive weight is more prevalent in older population [8], age was also an important obesity determinant in our results.

The rural inhabitancy was a particularly strong obesity determinant in our analysis. In the rural area, $39.8 \%$ of women and $40.2 \%$ of men had BMI over 30 $\mathrm{kg} / \mathrm{m}^{2}$, while in the urban area the prevalence was $26 \%$ and $26.4 \%$. This determinant was significant also in terms of central obesity. Traditionally it was believed, that urbanisation is associated with increasing rates of obesity. However, as the obesity epidemic rises, the urban-rural difference in aspect of adiposity tends to change. It has already been observed in high income countries. According to NHANES (2005-2008), $39.6 \%$ of rural adults and $33.4 \%$ of urban adults in USA had BMI over $30 \mathrm{~kg} / \mathrm{m}^{2}$. Rural residence was a significant obesity determinant even after controlling for sociodemographic, physical activity, and diet variables [10]. Probably rural residents in USA present more unhealthy behaviours, like consuming too much calories from fat [10], smoking [11], alcohol and drug use [12], and worse access to health care [13]. Living in metropolitan areas might be favourable to cardiovascular health [14]. Indeed, the mortality rates in USA are higher in rural than in urban areas, mostly due to heart disease and cancers [15]. This trend toward increase in adiposity increase in rural communities is becoming apparent also in low- and middle-income countries [16]. Also in the population of Polish-Norwegian Study (PONS) the obesity prevalence was higher in rural residents of Holy Cross Province in Poland [17]. 
There are other studies from Poland suggesting that residents of big cities have favourable cardiometabolic profile. Doryńska et al. compared a group of inhabitants of a Polish metropolis - Kraków (HAPIEE study) with whole Polish population (WOBASZ study). HAPIEE cohort had significantly higher education and employment rate, lower prevalence of active smokers and obese people, especially with central obesity [18]. In our study, employment was also a significant determinant of perceiving normal weight, although it has been observed only in women. It may be associated with urban/rural difference, because work possibilities for women are better in the cities. Recently Hughes et al. have shown, that male jobseekers had lower risk of being overweight, but it did not occur in women. Also non-smoking jobseekers had increased odds of obesity, while smoking decreased obesity risk in this group [19]. Similarly, in our study current smoking was a negative predictor of obesity in female group, while never or former tobacco use was associated with higher risk of obesity. Some authors confirm this finding [20], but it needs further studies.

Another important obesity determinant in our research was stress, especially related to family life. Similarly, in a group of Seoul inhabitants stress was significantly associated with obesity risk [20]. However, the effect of stress on body mass is probably variable. In the Whitehall II Study, work stress was related to weight gain in men with higher BMI at baseline, while men with lower baseline BMI had increased likelihood of weight loss [21]. Probably changes in body form in relation to stress are different depending on personal habituation processes (autonomic variation and psychological distress) [22].

In our study, individual factors modified obesity risk. The importance of family health history of (diabetes, hypertension) indicates some genetic predisposition, however no causality could be drawn out of cross sectional observation. We also examined occurrence of obesity risk allele A of FTO gene polymorphism rs9939609, which predisposes to higher odds of obesity in European populations [23]. However, this genetic factor appeared to be weak comparing to environmental factors, especially in women from our group. Another significant factor - chronic use of medication - was rather a result than cause of obesity. Also age was an important obesity determinant, which is consistent with other studies [8, 10,17].

Surprisingly, using oral contraception was associated with lower obesity risk in women in our cohort. Weight gain is often considered a side effect of hormonal contraceptives. However, there is no clear evidence in available data that combination contraceptives predispose to obesity [24]. Maybe in our cohort this result was associated with the effect of inhabitancy, because women in urban areas, who were less obese, more often use oral contraceptives.

In our results, sedentary leisure time activities, low physical activity, injury causing decrease in mobility in women and longer physical inactivity time in males were positively correlated with higher risk of adiposity. This is consistent to other author's findings $[10,20]$ and emphasises the need of healthy lifestyle promotion.

Our study has some limitations. It was a cross-sectional analysis, with higher female and middle-aged participants prevalence. In selected areas (according to PURE study design), people were allowed to register themselves and some snowball sampling biases are possible. However, the number of participants and recruitment both from urban and rural living areas gives advantage to our study.

\section{Conclusions}

In our analysis of obesity determinants in Lower Silesia, rural inhabitancy appeared to be an important obesity risk factor. Unemployment played significant role in female group. Other obesity determinants were stress, chronic use of medications, age, sedentary lifestyle, family burden. Smoking and oral contraception seemed to have protective impact against obesity in women. The prevalence of obesity in our cohort was high $-31 \%$ in both sexes.

\section{Funding sources}

This work was supported by Wroclaw Medical University grant programme - "Projects for Young Researchers" (Pbmn 158) in years 2013-2016.

\section{References}

1. Roberto CA, Swinburn B, Hawkes C, et al. Patchy progress on obesity prevention: emerging examples, entrenched barriers, and new thinking. Lancet. 2015; 385(9985): 2400-2409, doi: 10.1016/S0140-6736(14)61744-X, indexed in Pubmed: 25703111.

2. Lakerveld J, Mackenbach J. The Upstream Determinants of Adult Obesity. Obes Facts. 2017; 10(3): 216-222, doi: 10.1159/000471489, indexed in Pubmed: 28564658.

3. Kinra S, Nelder RP, Lewendon GJ. Deprivation and childhood obesity: a cross sectional study of 20,973 children in Plymouth, United Kingdom. J Epidemiol Community Health. 2000; 54(6): 456-460, indexed in Pubmed: 10818122.

4. Tremblay A, Lachance É. Tackling obesity at the community level by integrating healthy diet, movement and non-movement behaviours. Obes Rev. 2017; 18 Suppl 1: 82-87, doi: 10.1111/obr.12504, indexed in Pubmed: 28164447.

5. Ilow R, Regulska-Ilow B, Rozanska D, et al. Występowanie czynników ryzyka chorób sercowo-naczyniowych w grupie 40- i 50-letnich mieszkańców Wroclawia. Med Ogólna Nauki O Zdrowiu. 2012; 4: 435-441.

6. Teo K, Chow CK, Vaz M, et al. PURE Investigators-Writing Group. The Prospective Urban Rural Epidemiology (PURE) study: examining the impact of societal influences on chronic noncommunicable diseases in low-, middle-, and high-income countries. Am Heart J. 2009; 158(1): 1-7.e1, doi: 10.1016/j.ahj.2009.04.019, indexed in Pubmed: 19540385. 
7. Biela U, Pajak A, Kaczmarczyk-Chałas K, et al. [Incidence of overweight and obesity in women and men between the ages of 20-74. Results of the WOBASZ program]. Kardiol Pol. 2005; 63(6 Suppl 4): S632-S635, indexed in Pubmed: 20527435.

8. Stepaniak U, Micek A, Waśkiewicz A, et al. Prevalence of general and abdominal obesity and overweight among adults in Poland. Results of the WOBASZ II study (2013-2014) and comparison with the WOBASZ study (2003-2005). Pol Arch Med Wewn. 2016; 126(9): 662-671, doi: 10.20452/pamw.3499, indexed in Pubmed: 27535012.

9. Zdrojewski T, Rutkowski M, Bandosz P, et al. Ocena rozpowszechnienia i kontroli czynników ryzyka chorób serca i naczyń w Polsce — badania NATPOL 1997, 2002, 2011. In: Kopeć G., Jankowski P. Pająk A., Drygas W, eds. Epidemiologia i prewencja chorób układu krążenia. Medycyna Praktyczna, Kraków 2015: 57-64.

10. Befort CA, Nazir N, Perri MG. Prevalence of obesity among adults from rural and urban areas of the United States: findings from NHANES (2005-2008). J Rural Health. 2012; 28(4): 392-397, doi: 10.1111/j.1748-03 61.2012.00411.x, indexed in Pubmed: 23083085.

11. Roberts ME, Doogan NJ, Kurti AN, et al. Rural tobacco use across the United States: How rural and urban areas differ, broken down by census regions and divisions. Health Place. 2016; 39: 153-159, doi: 10.1016/j. healthplace.2016.04.001, indexed in Pubmed: 27107746.

12. Rhew IC, David Hawkins J, Oesterle S. Drug use and risk among youth in different rural contexts. Health Place. 2011; 17(3): 775-783, doi: 10.1016/j. healthplace.2011.02.003, indexed in Pubmed: 21414831.

13. Caldwell JT, Ford CL, Wallace SP, et al. Intersection of Living in a Rural Versus Urban Area and Race/Ethnicity in Explaining Access to Health Care in the United States. Am J Public Health. 2016; 106(8): 1463-1469, doi: 10.2105/AJPH.2016.303212, indexed in Pubmed: 27310341.

14. Lawrence E, Hummer RA, Harris KM. The Cardiovascular Health of Young Adults: Disparities along the Urban-Rural Continuum. Ann Am Acad Pol Soc Sci. 2017; 672(1): 257-281, doi: 10.1177/0002716217711426, indexed in Pubmed: 28694547.
15. Cossman JS, James WL, Cosby AG, et al. Underlying causes of the emerging nonmetropolitan mortality penalty. Am J Public Health. 2010; 100(8): 1417-1419, doi: 10.2105/AJPH.2009.174185, indexed in Pubmed: 20558803.

16. Jaacks LM, Slining MM, Popkin BM. Recent trends in the prevalence of under- and overweight among adolescent girls in low- and middle-income countries. Pediatr Obes. 2015; 10(6): 428-435, doi: 10.1111/ijpo.12000, indexed in Pubmed: 25558987.

17. Zatońska K, Janik-Koncewicz K, Regulska-Ilow B, et al. Prevalence of obesity - baseline assessment in the prospective cohort 'PONS' study. Ann Agric Environ Med. 2011; 18(2): 246-250, indexed in Pubmed: 22216790.

18. Doryńska A, Polak M, Kozela M, et al. Cardiovascular disease (CVD) risk factors in Kraków and in the whole Poland adult population. Results from the WOBASZ study and Polish arm of the HAPIEE project. Przegl Epidemiol. 2015; 69(1): 79-86, 175, indexed in Pubmed: 25862452.

19. Hughes A, Kumari M. Unemployment, underweight, and obesity: Findings from Understanding Society (UKHLS). Prev Med. 2017; 97: 19-25, doi: 10.1016/j.ypmed.2016.12.045, indexed in Pubmed: 28034731

20. Kim J, Shon C, Yi S. The Relationship between Obesity and Urban Environment in Seoul. Int J Environ Res Public Health. 2017; 14(8), doi: 10.3390/ijerph14080898, indexed in Pubmed: 28792465.

21. Kivimäki M, Head J, Ferrie JE, et al. Work stress, weight gain and weight loss: evidence for bidirectional effects of job strain on body mass index in the Whitehall II study. Int J Obes (Lond). 2006; 30(6): 982-987, doi: 10.1038/sj.ijo.0803229, indexed in Pubmed: 16418750.

22. Kubera B, Leonhard C, Rößler A, et al. Stress-Related Changes in Body Form: Results from the Whitehall II Study. Obesity (Silver Spring). 2017; 25(9): 1625-1632, doi: 10.1002/oby.21928, indexed in Pubmed: 28767203

23. Dina C, Meyre D, Gallina S, et al. Variation in FTO contributes to childhood obesity and severe adult obesity. Nat Genet. 2007; 39(6): 724-726, doi: 10.1038/ng2048, indexed in Pubmed: 17496892.

24. Gallo MF Lopez LM, Grimes DA et al Combination contraceptives: effects on weight. Cochrane Database Syst Rev. 2006(1): CD003987, doi: 10.1002/14651858.CD003987.pub2, indexed in Pubmed: 16437470. 